\section{Organization of cervical cancer screening in Campinas and surrounding region, São Paulo State, Brazil}

\author{
Organização do rastreamento do câncer \\ do colo uterino em Campinas e região, \\ São Paulo, Brasil
}

Luiz Carlos Zeferino 1,2

José A. Pinotti 1,2,3

Jessé P. Neves Jorge 1,2

Maria Cristina A. Westin 2

Julia K. Tambascia ${ }^{2}$

Eliana B. L. Montemor 2
1 Faculdade de Ciências Médicas, Universidade Estadual de Campinas, Campinas, Brasil.

2 Centro de Assistência Integral à Saúde da Mulher, Universidade Estadual de Campinas, Campinas, Brasil. 3 Faculdade de Medicina, Universidade de São Paulo São Paulo, Brasil.

Correspondence L. C. Zeferino Departamento de Tocoginecologia, Faculdade de Ciências Médicas, Universidade Estadual de Campinas. Rua Alexander Fleming 101, Campinas, $S P$

13083-881, Brasil.

zeferino@caism.unicamp.br

\begin{abstract}
Cervical cancer screening remains a challenge in developing countries due to a complex array of problems. This paper aimed to describe the experience with organization of cervical cancer screening in three districts of Campinas and the surrounding region in São Paulo State, Brazil, and to report the resulting data. The program was organized in a pyramid format, and the health care hierarchy was defined according to the complexity and total number of medical procedures. Screening has been extended currently to 88 municipalities, of which 51 are equipped with colposcopy and eight have facilities for treating advanced cervical cancer. The standardized incidence rate for cervical cancer in Campinas was 14.2/100,000 women per year in 1993-1995, and the standardized mortality rate per district ranged from 2.7 to 3.0 per 100,000 women in 1997-1998. This project has clearly shown that hierarchical and decentralized organization of health procedures is a necessary condition for achieving the goals of an effective cervical cancer screening program.
\end{abstract}

Cervix Neoplams; Cytology; Papanicolaou Smear; Mortality; Health Services

\section{Introduction}

Cervical cancer is a public health problem in developing countries, where socioeconomic conditions are precarious and screening programs for this disease often fail to achieve their objectives, resulting in high mortality rates 1 . In Brazil, despite government efforts, the cervical cancer mortality rate has remained unchanged for the last 20 years 2 . Therefore, the expansion of screening programs and reduction in mortality remain a challenge, due to a complex array of problems that go far beyond the introduction of simplified technology such as visual inspection with acetic acid. Women with abnormal Pap smears must be guaranteed easy access to health care for diagnostic and therapeutic procedures, or many will fail to obtain the required treatment 3 .

In 1968 a cervical cancer screening program was implemented in Campinas and the surrounding region in São Paulo State (Southeast Brazil), and in recent years the region has shown a reduction in cervical cancer mortality 4 . This paper thus aims to describe a steady process in this region with the organization of health services related to cervical cancer screening in order to highlight some strategic issues for the expansion of this service and provide key data on cervical cancer incidence and mortality rates. 
The Campinas cervical cancer screening program: background

The cervical cancer screening program was implemented in 1968 in the city of Campinas, after which it was progressively extended to cover other municipalities (or counties) in the region. At the time, the health system was poorly organized and most health care was centralized in hospitals. However, the model established that collection of Pap smear samples should be decentralized to medical and nonmedical personnel previously trained at the State University in Campinas. A cytopathology laboratory was created at the State University, where the hospital provided full treatment and follow-up for women with abnormal exams. In addition to limited resources, another obstacle was that due to professional identity issues, physicians objected to involvement of nonmedical personnel in the project and disagreed with the centralization of the laboratory 5 .

By 1984, due to the increased demand for these services, it was no longer possible to expeditiously examine all women referred to the teaching hospital with abnormal Pap smears. In order to avoid long delays in patient examination and a resulting backlog in the screening program, a strategy was needed to decentralize diagnostic and therapeutic procedures for this group of women 5 . Therefore, a partnership with local health authorities was established in 1985 to implement the secondary tier of the screening program. The first eight decentralized outpatient clinics were organized to perform colposcopy, cervical biopsies, and electrocautery therapy in patients whose biopsies showed mild to moderate cervical dysplasia. Gynecologists were hired and trained and the decentralized services were properly equipped. The municipalities thus began to share the responsibility for offering complementary health care to women with abnormal exams, and some also began to outsource services to private local cytopathology laboratories 6 .

In 1988, the Brazilian Ministry of Health issued a standard recommendation that cervical screening should begin at 25 years of age and be performed annually for two consecutive years. If these initial Pap smears are negative, subsequent smears should then be performed every three years up to the age of 607 .
The Campinas cervical cancer screening program: current organization

According to current organization of the health service administration for cervical cancer screening, in 2002 the Campinas region consisted of 88 municipalities and was organized for this purpose into three Districts, Campinas, Piracicaba, and São João da Boa Vista (Figure 1), with homogeneous socioeconomic profiles. In 2002 there were $1,839,182$ women $\geq 20$ years of age in the region, and an estimated $60 \%$ of this population used the public health system 8 . All 88 municipalities have provided cervical cancer screening since 1990. In 2002, the University's cytopathology laboratory received Pap smears from 388 community health care centers belonging to the public health system in 61 municipalities. The greatest distance between any municipality and Campinas is approximately 200 kilometers. Twenty-seven municipalities outsourced their Pap smears to local cytopathology laboratories.

Through decentralization of cervical cancer screening activities, the municipalities gradually became more efficient, and 51 municipalities are currently capable of providing at least colposcopy, with some offering cold knife conization and hysterectomy. Eight provide at least partial tertiary medical care for diagnosis and treatment of patients with invasive cervical cancer.

Since the program began, cervical cancer screening in the public health system, including diagnosis and treatment of detected lesions, has been provided free of charge.

\section{Data sources}

Data on Pap smears performed annually from 1995 to 2002 was provided by SUS Department of Data and Information Technology (Departamento de Informação e Informática do SUS DATASUS), the information and statistics office of the Unified National Health System (Sistema Único de Saúde - SUS), representing the Ministry of Health 9. Data from 1968 to 2002 were retrieved from the database of the University's cytopathology laboratory, which since 1998 has included the use of a detailed form designed for optical mark readers. Information on cancer incidence in Campinas was provided by the population-based Campinas Cancer Registry, published in Cancer Incidence in Five Continents, Volume VIII 10. Mortality rates for the Campinas area were provided by Fundação Oncocentro de São Paulo (FOSP), a government health agency in the State of São Paulo dealing 
with statistics on cancer 4 . There is no information available on Pap smears currently performed by private clinics and laboratories.

\section{Results}

In 2002 , a total of 402,027 cervical smears (54.7\% more than in 1995 ) were performed by laboratories in the public health system in the three Districts. The university's laboratory performed most of the cervical smears (Table 1). Considering only the female population $\geq 20$ years of age, $21.9 \%$ had a Pap smear in the public health system in 2002 (data not shown).

According to the Campinas Cancer Registry, the standardized cervical cancer incidence rate for 1993-1995 was 14.2 new cases per 100,000 women per year 10 .

Standardized mortality rates for cervical cancer in 1997-1998 were 3.0, 2.7, and 3.0 per 100,000 women per year in the Districts of Campinas, Piracicaba, and São João da Boa Vista, respectively. The three Districts showed decreases of $37.5 \%, 20.6 \%$, and $25 \%$, respectively, in standardized mortality rates for cervical cancer, comparing 1987-1988 and 1997-1998 (Table 2). Cervical cancer is the eighth most common cause of death from cancer in women in all three Districts 4.

\section{Discussion}

The cervical cancer incidence and mortality rates achieved in Campinas and the surrounding region are similar to those in many developed countries and are far better than elsewhere in Brazil and in other developing countries. Estimates by the International Agency for Research on Cancer (IARC) predicted 23.4 new cases of cervical cancer per 100,000 women in Brazil in the year 200211 . In 1993, the standardized cervical cancer incidence rate for São Paulo, the largest city in Brazil, was 27.9 new cases per 100,000 women 9, twice the rate for Campinas in 1993-1995 11.

IARC also predicted a standardized cervical cancer mortality rate of 10.2 per 100,000 women in Brazil for the year 2002, making this neoplasm the second most frequent cause of death from cancer in Brazil, next to breast cancer. In South America, Uruguay has the lowest cervical cancer mortality rate $(7.0 / 100,000)$, while Bolivia has the highest $(30.4 / 100,000)$. In Central and Eastern European countries, the mortality rate is 7.1 per 100,000 women 12 .

Reduction in the cervical cancer incidence and mortality rates is a difficult goal to achieve,
Districts of Campinas, Piracicaba, and São João da Boa Vista, São Paulo, Brazil. Geographic area covered by the cervical cancer screening program.
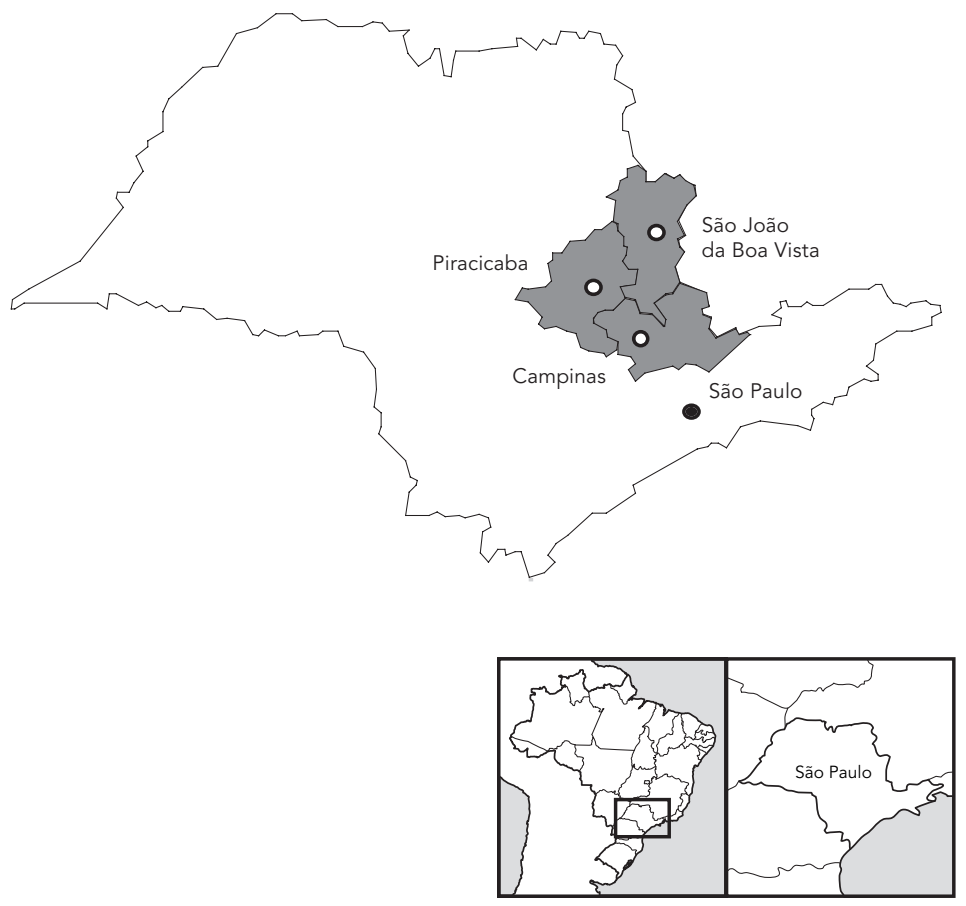

even in developed countries. In the United Kingdom, before the introduction of the national call and recall system and incentive payments to general practitioners, the cervical cancer screening program was ineffective, due mainly to organizational problems. Most cytological tests had been performed on women presenting for obstetrical, gynecological, or contraceptive consultation. Data showed that at least twothirds of women with invasive cervical cancer had never been screened, and more than $90 \%$ of women over 40 years of age had never been screened 13 . These data show that many women were excluded from cervical cancer screening in the UK.

Our results indicate that hierarchical and decentralized organization was probably the most important factor for achieving the reduction in incidence and mortality rates. Initially, before the heath services had been integrated, it was necessary to create a specific cervical cancer screening system, which posed numerous challenges. It was absolutely necessary to decentralize the collection of Pap smear sam- 
Total number of Pap smears performed annually from 1995 to 2002 in the Campinas region, São Paulo State, Brazil.

\begin{tabular}{|c|c|c|c|c|c|}
\hline \multirow[t]{2}{*}{ Year } & \multicolumn{2}{|c|}{$\begin{array}{l}\text { University of Campinas } \\
\text { cytopathology laboratory }\end{array}$} & \multicolumn{2}{|c|}{$\begin{array}{c}\text { Other cytopathology } \\
\text { laboratories* }\end{array}$} & \multirow[t]{2}{*}{ Total } \\
\hline & Number of tests & $\%$ & Number of tests & $\%$ & \\
\hline 1995 & 139,435 & 63.2 & 81,175 & 36.8 & 220,610 \\
\hline 1996 & 147,317 & 65.7 & 77,056 & 34.3 & 224,373 \\
\hline 1997 & 193,249 & 74.4 & 66,503 & 25.6 & 259,752 \\
\hline 1998 & 219,290 & 79.3 & 57,275 & 20.7 & 276,565 \\
\hline 1999 & 221,572 & 79.4 & 57,613 & 20.6 & 279,185 \\
\hline 2000 & 219,635 & 75.2 & 72,274 & 24.8 & 291,909 \\
\hline 2001 & 235,212 & 61.0 & 150,238 & 39.0 & 385,450 \\
\hline 2002 & 289,837 & 72.1 & 112,190 & 27.9 & 402,027 \\
\hline
\end{tabular}

* Data from DATASUS 9.

Table 2

Crude and standardized mortality rates for cervical cancer according to District: 1987-1998.

\begin{tabular}{|c|c|c|c|c|c|c|c|c|}
\hline \multirow[t]{2}{*}{ District } & \multicolumn{4}{|c|}{ Crude rate } & \multicolumn{4}{|c|}{ Standardized rate } \\
\hline & 1987-1988 & 1992-1993 & 1997-1998 & Reduction (\%)* & 1987-1988 & 1992-1993 & 1997-1998 & Reduction (\%)* \\
\hline Campinas & 4.6 & 4.7 & 3.4 & 26.1 & 4.8 & 4.5 & 3.0 & 37.5 \\
\hline Piracicaba & 3.4 & 3.6 & 3.1 & 8.8 & 3.4 & 3.4 & 2.7 & 20.6 \\
\hline São João da Boa Vista & 4.0 & 3.8 & 3.3 & 17.5 & 4.0 & 3.6 & 3.0 & 25.0 \\
\hline
\end{tabular}

* Percentage reduction in mortality rate from1987-1988 to 1998-1997.

Source: Fundação Oncocentro de São Paulo 4.

ples by delegating the procedure to medical and non-medical personnel at various sites in each municipality, to facilitate patient access and achieve high coverage. One important role of the local personnel was also to locate and refer all patients with abnormal Pap smears for complementary health care, a role for which the centralized cytopatology laboratory had proven inefficient. Decentralization of colposcopy clinics was another challenge, since long delays in patient examinations had tended to reduce compliance and more women were being lost to follow-up treatment. The program's target population has low socioeconomic status, so the goal was to improve compliance by decentralizing colposcopy rather than attempting to call and recall the patients from a large region to be treated in a centralized hospital (while comprehensive centers were to preferentially provide more specialized diagnostics and treatment).

Therefore the cervical cancer screening program in the three Districts of Campinas is organized as a pyramid, and the health care hierarchy was established according to the complexity and number of medical procedures. Pap smears are now taken routinely as primary health care in all 88 municipalities, so the exams are at the primary tier in the pyramid. The colposcopy clinics, at the secondary level, provide the connection between the primary level and comprehensive hospitals. Treatment of invasive cervical carcinoma is concentrated in a few comprehensive centers, and at the top of the pyramid. The teaching hospital currently receives patient overflow from other municipalities where the demand is high, as well as patients whose disease requires diagnostic and therapeutic procedures unavailable at their local health services. This is a highly important role for guaranteeing the effectiveness of cervical cancer screening.

In most developed countries, the pyramidlike organization is obvious and natural, since the entire heath system works through this for- 
mat. Developed countries also tend to have personal health information systems that make it feasible to identify patients who fail to appear for their follow-up appointments 14. However, such data are not available in Brazil, where the health information system is based on the number of Pap smears actually performed rather than on the total adult female population (a situation similar to that of other less developed countries) 15 .

This limitation of the Brazilian health information system makes it impossible to implement an effective call and recall system, an important condition for reaching the women who were not included in the screening program. Five international organizations recently implemented the Alliance for Cervical Cancer Prevention (ACCP) that has been working to identify effective ways to increase women's voluntary participation in preventive programs by testing strategies for community involvement in developing countries. One of the aims of this alternative is to resolve the gaps in the health information system 16 .

The main focus of the discussion on cervical cancer screening in developing countries has been the screening tool 17,18. In regions with under-resourced health services, the use of more simplified technology for cervical cancer screening (such as visual inspection) could be a facilitating factor. However, this is insufficient if an organized network of health procedures is not in operation in order to guarantee high coverage and assure diagnostic and thera- peutic efficacy for women with abnormal test results 3,19 . In fact, the failure of cervical cancer screening in developing countries may be due more to failures in organizational programs than to technological limitations of the screening test.

In $2002,21.9 \%$ of women aged 20 or older had Pap smears performed in the public health system in Campinas and surrounding region. Data from private clinics is not available for the same year, but based on data from previous years, at least $20 \%$ of women are estimated to have had Pap smears in private clinics 6 . Thus approximately $40 \%$ of women in this age group had Pap smears in 2002. This is a high rate for one year, suggesting that the time between tests has been less than three years, thus representing a waste of resources.

In short, screening is an ongoing process that involves decentralization of procedures, educating the population at large, upgrading medical procedures, extending the operational capacity of health services, optimizing the available resources, and offering operational flexibility and compatibility with other healthcare demands. The experience acquired in the current project has clearly shown that the hierarchical and decentralized organization of health procedures constitutes a key component for an effective cervical cancer screening program. Thus, reduction of cervical cancer mortality is a major challenge for developing countries, regardless of the screening tools used for the detection of precursor lesions.

\section{Resumo}

O programa de rastreamento do câncer do colo uterino ainda é um desafio para os países em desenvolvimento devido a uma série complexa de problemas. Este estudo objetivou descrever a experiência adquirida com a organização e mostrar alguns dados sobre o rastreamento deste câncer em três distritos de Campinas e região, São Paulo, Brasil. A hierarquia das ações de saúde foi estabelecida de acordo com a complexidade dos procedimentos e do total destes procedimentos que precisavam ser realizados. Atualmente, o rastreamento se estende a 88 municípios, dos quais 51 realizam colposcopia e oito têm serviços para tratar cân- cer avançado do colo uterino. A taxa de incidência ajustada em Campinas foi de 14,2/100 mil mulheres por ano em 1993-1995, e a taxa de mortalidade ajustada por distrito variou entre 2,7 e 3,0 por $100 \mathrm{mil}$ mulheres em 1997-1998. De acordo com a experiência adquirida, a organização hierárquica e descentralizada dos procedimentos constituiu-se como condição necessária para alcançar alguns dos objetivos do rastreamento do câncer do colo uterino.

Neoplasias do Colo Uterino; Citologia; Esfregaço Vaginal; Mortalidade; Serviços de Saúde 


\section{Contributors}

L. C. Zeferino analyzed the data and wrote the article. J. A. Pinotti analyzed and revised the article. J. P. N. Jorge revised the article. M. C. A. Westin analyzed the data and revised the article. J. K. Tambascia revised the article. E. B. L. Montemor was responsible for the laboratory databank and participated in the data analysis.

\section{References}

1. Eluf-Neto J, Nascimento CMR. Cervical cancer in Latin America. Semin Oncol 2001; 28:188-97.

2. Ministério da Saúde/Instituto Nacional de Câncer. Taxas de mortalidade das 5 localizações primárias de câncer mais freqüentes em 1999, ajustadas por idade pela população padrão mundial, por 100.000 homens e por 100.000 mulheres, entre 1979 e 1999. In: Atlas de mortalidade por câncer no Brasil, 1979-1999. http://www.inca.gov. br/atlas/docs/txmortalidade_5loc.pdf (accessed on $08 / \mathrm{Jul} / 2004$ ).

3. Agurto I, Bishop A, Sanchez G, Betancourt Z, Robles S. Perceived barriers and benefits to cervical cancer screening in Latin America. Prev Med 2004; 39:91-8.

4. Fundação Oncocentro de São Paulo, Secretaria de Estado da Saúde de São Paulo. Mortalidade por câncer no Estado de São Paulo 1988-1998. São Paulo: Fundação Oncocentro de São Paulo; 2000.

5. Pinotti JA, Zeferino LC. Programa de controle de câncer cérvico uterino. Campinas: Editora da Unicamp; 1997.

6. Zeferino LC, Costa AM, Morelli MGLO, Tambascia J, Panetta K, Pinotti JA. Programa de detecção do câncer do colo uterino de Campinas e Região: 1968-1996. Rev Bras Cancerol 1999; 45:25-33.

7. Ministério da Saúde/Instituto Nacional de Câncer. Recomendações básicas para o controle de câncer do colo de útero no Brasil. Rev Bras Cancerol 2000; 46:23-33.

8. Secretaria de Estado da Saúde de São Paulo. Informações de saúde. Informações demográficas e sócio-econômicas. http://www.saude.sp.gov.br/ informacoes_saude/dados_saude/html/dados_s aude_dem_socio.html (accessed on 30/Jan/2004).

9. Departamento de Informática do SUS. SISCAM: informações estatísticas. http://www.datasus.gov. br (accessed on 25/May/2005).

10. Parkin DM, Whelan SL, Ferlay J, Teppo L, Thomas $\mathrm{D}$, editors. Cancer incidence in five continents. $\mathrm{v}$. VIII. Lyon: International Agency for Research on Cancer; 2003. (IARC Scientific Publication, 155).
11. Faculdade de Saúde Pública, Universidade de São Paulo. Registro de câncer de São Paulo. http:// www.fsp.usp.br/rcsp (accessed on 24/May/2005).

12. International Agency for Research on Cancer. The Globocan 2002 database. http://www.iarc.fr (accessed on 24/May/2005).

13. Quinn M, Babb P, Jones J, Allen E. Effect of screening on incidence of and mortality from cancer of cervix in England: evaluation based on routinely collected statistics. BMJ 1999; 318:904-8.

14. Anttila A, Ronco G, Clifford G, Bray F, Hakama M, Arbyn $\mathrm{M}$, et al. Cervical cancer screening programmes and policies in 18 European countries. Br J Cancer 2004; 91:935-41.

15. Thomas JO, Babarinsa IA, Ajayi IO, Fawole O, Ojemakinde KO, Omigbodun AO. Mobilization for cervical cancer screening: lessons from a poor urban Yoruba community in Nigeria. Afr J Med Med Sci 2005; 34:81-5.

16. Agurto I, Arrossi S, White S, Coffey P, Dzuba I, Bingham A, et al. Involving the community in cervical cancer prevention programs. Int J Gynaecol Obstet 2005; 89 Suppl 2:S38-45.

17. Blumenthal PD, Gaffikin L, Chirenje ZM, McGrath J, Womack S, Shah K. Adjunctive testing for cervical cancer in low resource settings with visual inspection, HPV, and the Pap smear. Int J Gynaecol Obstet 2001; 72:47-53.

18. Cronje HS. Screening for cervical cancer in developing countries. Int J Gynaecol Obstet 2004; 84: 101-8.

19. Lazcano-Ponce E, Alonso P, Ruiz-Moreno JA, Hernandez-Avila M. Recommendations for cervical cancer screening programs in developing countries. The need for equity and technological development. Salud Pública Méx 2003; 45 Suppl 3: S449-62.

Submitted on $23 / \mathrm{Jul} / 2004$

Final version resubmitted on 13/Jul/2005

Approved on 17/Aug/2005 